\title{
Role of Reactive Oxygen Species in Defense Responses Against Chocolate Spot Disease in Resistant and Susceptible Faba Bean (Viciafaba) Cultivars
}

\author{
Mostafa A. Amer ${ }^{1}$, Ibrahim A. El-Samra ${ }^{1}$,Sawsan M. El-Abd ${ }^{1}$,Ayman F. \\ Omar $^{2}$, MunaN. Ekrim ${ }^{1}$ and Amero A.Emeran ${ }^{2}$
}

\author{
${ }^{1}$ Agricultural Botany Department, Faculty of Agriculture (Saba-Basha), Alexandria \\ University, P.O. Box 21531- Bolkley, Alexandria, Egypt. \\ ${ }^{2}$ Agricultural Botany Department, Faculty of Agriculture, Kafr el-Sheikh \\ University, Egypt
}

Corresponding author: MostafaAmer, e-mail: maaamer@hotmail.com

\begin{abstract}
Three infected faba bean (FB) plant cultivars (susceptible and resistant to Botrytis fabae Sard.) were pretreated with three tested biological inducers (Trichoderma viride, Talaromyces stipitatus and Verticillium lecanii). Disease index (DI) and disease severity (DS) were significantly reduced as a result of all treatments, Giza 40 showed less reduction compared with the infected and uninfected control. Later on activities of peroxidase (POD) and polyphenol oxidase (PPO), two infected bean cultivars were increased significantly compared with control. Treatment with the tested biological inducers resulted in significant increase in POD enzyme activity early at $24 \mathrm{hrs}$ after inoculation of both susceptible (Giza 40) and resistant (Sakha2) cultivars with B. fabae, compared with the treated control. Moreover, T. stipitatus bioinducer recoded the highest POD activity values in all the tested cultivars. PPO enzyme activity significantly increased when pretreated resistant cv (Sakha2) with $T$. stipitatus and suceptible cv (Giza 40) with V. lecanii, compared with the other tested treatments. Increases in PPO activity were early observed in all treatments, except for $T$. stipitatus-Giza $40 \mathrm{cv}$ treatment. Increases and accumulation of reactive oxygen species (ROS), mainly superoxide $\left(\mathrm{O}_{2}{ }^{-}\right)$were detected at early stages (24 hrs) after inoculation due to pretreatment with $V$. lecanii, compared to untreated control of Giza 40 and treated control of Sakha2, gaving the same results. At the meantime, it was found that pretreatment of Giza 40 and control with T. stipitatus significantly increased and accumulated levels of $\left(\mathrm{O}_{2}{ }^{-}\right)$at late stages (72 hrs) after inoculation. It was also noted that all treatments resulted in significant increase and accumulation of $\mathrm{O}_{2}{ }^{-}$, except for Giza $40 \mathrm{cv}$, which showed pronounced decrease in $\mathrm{O}_{2}{ }^{-}$levels. In spite of the increase and accumulation of hydrogen peroxide $\left(\mathrm{H}_{2} \mathrm{O}_{2}\right)$, detected in all treatments $72 \mathrm{hrs}$ after inoculation, however, pretreated control of Giza $40 \mathrm{cv}$ showed early increase and accumulation of $\mathrm{H}_{2} \mathrm{O}_{2} 24 \mathrm{hrs}$ after inoculation. Positive relationship between accumulated $\mathrm{of}_{2} \mathrm{H}_{2} \mathrm{O}_{2}$ and the time elapsed after inoculation was observed in all the tested treatments.

Keywords: bio-agents inducers, faba bean, Botrytis fabae, Trichoderma viride, Talaromyces stipitatus, Verticillium lecanii, disease index (DI), disease severity (DS), peroxidase (POD), polyphenol oxidase (PPO), superoxide $\left(\mathrm{O}_{2}{ }^{\prime}\right)$ and hydrogen peroxide $\left(\mathrm{H}_{2} \mathrm{O}_{2}\right)$.
\end{abstract}

\section{INTRODUCTION}

Faba bean (Vicia faba L.) is subjected to many abiotic and biotic stresses that seriously compromise the final yields (El-Hendawy et al., 2010). Among the biotic stresses, the chocolate spot disease caused mainly by Botrytis fabae Sard, and to some extent $B$. cinerea Pers. is one of the most economically important diseases that damage the foliage, limit photosynthesis activity, and reduce FB production (Torres et al.,2004). Chocolate spot is one of the most important diseases infecting FB in Egypt. In Morocco, Nile Delta or African regions, losses in yield due to chocolate spot disease can reach $60-80 \%$ among susceptible cultivars and up to $34 \%$ among tolerant cultivars (Bouhassan et al., 2004, and Sahileet al.,2008). Chocolate spot, which is incited by the necrotrophic plant pathogen Botrytis fabae Sard., is one of the devastating diseases of FB (Vicia faba L.) production worldwide (Rhaïem et al., 2002, and 
Torres et al., 2004), including Egypt (Abo-Hegazy et al., 2012,Abou-Zeidet al., 1990, Khalil and Harrison, 1981). The pathogen attacks all of the aboveground parts of the FB plant, thereby causing chocolate-colored lesions that may spread quickly around the infection site, killing the tissue above the lesion (Bouhassan et al., 2004). In Egypt, yield losses exceed 20-25\% (Khalil et al., 1993) and may reach 100\% under severe epidemic conditions (Bouhassan et al., 2004, and Torres et al., 2004). The deployment of resistant FB varieties is an efficient strategy for controlling the disease and promoting the development of sustainable agriculture (Bouhassan et al., 2004, and Rhaïem et al., 2002). However, only limited studies exist on the defense responses of the $\mathrm{FB} \times B$. fabae interaction (Sillero et al., 2010, and El-Komy, 2014). The results of ElKomyet al. (2015) indicated that the chocolate spot pathogen induced lipid peroxidation and the production of reactive oxygen species, peroxidase (POD), and polyphenol oxidase (PPO) in leaf tissue during the $\mathrm{FB} \times B$. fabae interaction. The production of these defense compounds in leaves was not static but governed in time and extent by physiological maturity.

Plants defend themselves against fungal infection through the activation of complex defense responses (Dangl and Jones, 2001). One of the earliest these responses is the rapid generation of reactive oxygen species (ROS), which includes superoxide anion $\left(\mathrm{O}_{2}{ }^{-}\right)$, hydroxyl radical $\left(\mathrm{OH}^{\circ}\right)$ and hydrogen peroxide $\left(\mathrm{H}_{2} \mathrm{O}_{2}\right)$ (Patykowski and Urbanek, 2003). There are numerous studies demonstrating the production of these free radicals in plants as an initial response to microorganisms, both pathogenic and non-pathogenic (Bolwellet al., 2002, Garcia-Limoneset al., 2002, and Gill and Tuteja, 2010). ROS may have multiple effects on defense responses, including direct antimicrobial action, lignin biosynthesis, phytoalexin production and the triggering of systemic acquired resistance (Bradelyet al., 1992,Lamb and Dixon, 1997, Laloiet al., 2004, and Peng and Kuć, 1992). Nevertheless, the excess ROS causes oxidative damage, leads to lipid peroxidation and damages macromolecules such as pigments, proteins, nucleic acids and lipids (Apel and Hirt, 2004). To limit oxidative damage, plants have a defense antioxidative system to modulate the cytotoxic effects of these free radicals, which include enzymes such as superoxide dismutase (SOD), peroxidase (POX), ascorbate peroxidase (APX) and catalase (CAT) (Mittler, 2002). However, the role of ROS in the defense mechanism against necrotrophic fungi (e.g., Botrytis spp.) remains controversial (Asselberghet al., 2007). Some studies have demonstrated a positive effect of ROS on plant resistance (Malolepsza and Urbanek, 2000, and Unger et al., 2005). In contrast, other studies have demonstrated that the level of ROS accumulation in plant tissues was proportionally correlated with the aggressiveness of the necrotrophic pathogens (Govrin and Levine, 2000, Mayer et al., 2001, and von Tiedemann, 1997).

The aim of this study was to identify reliable biological inducers pretreatments on FB resistance against chocolate spot. In this regard, the disease severity and the accumulation levels of POD and PPO enzymes as well as $\mathrm{O}_{2}{ }^{-*}, \mathrm{H}_{2} \mathrm{O}_{2}$, were investigated in, resistant Sakha 2 and susceptible Giza 40 FB cvs. 


\section{MATERIALS AND METHODS}

\section{Sources of cultivars}

Three FB cultivars (Giza 40, Nubaria 1 and Sakha 2) were used throughout this investigation. These cultivars were obtained from Agricultural Research Center (ARC), Giza, Egypt, Nubaria Agriculture Research Centre, (ElBeheira) and Sakha Agriculture Research Centre (Kafr-El Sheikh).

\section{Sources of fungal isolates}

Botrytis fabae isolate (F3) were used throughout this study. Two biological inducer agents, including $T$. viride and $T$. stipitatus were obtained from the stock cultures from Laboratory of Plant Pathology, Agriculture Botany department at Agriculture Faculty (Saba-Basha), Alexandria University, whereas one fungal isolate, $V$. lecanii (Zimmerman) were obtained from Alaska, USA and EMCC Number: 919 ${ }^{\mathrm{TM}}$ (Egypt microbial culture collection).

\section{Experiments assay}

FB seeds of Sakha 2 and Nubaria 1 resistant cvs and the susceptible cv Giza 40 were surface-sterilized with $1 \%$ sodium hypochlorite for 30 second and then rinsed in sterile distilled water and dried under a sterile air stream, and then were sown in plastic pots under greenhouse conditions.

The bio-based resistance inducerisolates $T$. viride, $T$. stipitatusand $V$. lecanii were cultivated on potato dextrose agar medium (PDA) at $25^{\circ} \mathrm{C}$ and maintained at $4{ }^{\circ} \mathrm{C}$.Suspensions of bio-inducerswas prepared in sterile distilled water from 7-days-old-culture on PDA (Rojo et al., 2007). The fungal inoculum was harvested by flooding the culture with sterile distilled water (SDW) $(10 \mathrm{ml})$, and then rubbing the culture surface with a sterile glass rod. The concentration of bio-inducers was adjusted to $1.0 \mathrm{E} 07$ spores $/ \mathrm{ml}$ by dilution and direct counting using a haemocytometer (Emiko et al., 2008, andAbd El-Rahman and Mohamed, 2014).

Forty days after sowing, the growing plants were sprayed until dropping with an individual spore suspension of the tested bio-inducers ( $T$. viride, $T$. stipitatus and $V$. lecanii), at concentration $1.0 \mathrm{E} 07 \mathrm{spores} / \mathrm{ml}$ on lower leaf surface (first and second leaves). Tween20was added to spore suspension at concentration of $0.03 \%$. Four days later, plants were sprayed with bio-inducers, with spore suspension of the tested pathogen at concentration (2.5E05 spores $/ \mathrm{ml}$ ). Control plants were sprayed with pathogen spore suspension only (without bio-inducers), whereas, plants sprayed with distilled water only were used as untreated non infected control. All cultivated pots were covered with polyethylene bags for 24 hrs under greenhouse conditions. Each treatment was represented by four pots served as a replicates. Disease severity was calculated using the devised scale of Bernier et al. (1993). Chocolate spot symptoms, appeared 7 days after inoculation, were scored as disease index (\%) and disease severity (\%) assessed according to Bernier et al. (1984) as follows: 
Where:

$$
\text { Disease severity (DS) } \%=\frac{\Sigma(\mathrm{NPC} \times \mathrm{CR})}{\mathrm{NIP} \times \mathrm{MSC}} \times 100
$$

$\mathrm{NPC}=$ No. of plants in each class rate

$\mathrm{CR}=$ Class rate

NIP $=$ No. of infected plants

MSC $=$ Maximum severity class rate

$$
\text { Disease index }(\mathrm{DI}) \%=\frac{\text { number of infected plants }}{\text { total number of examined plants }} \times 100
$$

\section{Preparation of samples for physiological and biochemical experiments}

After inoculation of plants with $B$. fabae, entire leaves (fourth and fifth) of each individual plant were collected and pooled at each sampling time (24, 48 and $72 \mathrm{hrs}$ ) and frozen in liquid nitrogen and kept at $-80 \mathrm{C}^{\circ}$. These samples were then used for the preparation of total leaf homogenates required for enzymes assays.

\section{Determination of enzymes activities}

For determining enzyme activities of peroxidase (POD)and polyphenol oxidase (PPO)in plants, $0.5 \mathrm{~g}$ leaf material was homogenized at $0-4^{\circ} \mathrm{C}$ in $3 \mathrm{ml}$ of $50 \mathrm{mM}$ TRIS buffer ( $\mathrm{pH}$ 7.8), containing $1 \mathrm{mM}$ EDTA-Na2 and 7.5\% polyvinylpyrrolidone (24, 48 and 72 , hrs) after inoculation. The homogenates were centrifuged $\left(12,000 \mathrm{rpm}, 20 \mathrm{~min}, 4^{\circ} \mathrm{C}\right)$, and the total soluble enzyme activities were measured spectrophotometrically in the supernatant (Hafez, 2010). All measurements were carried out at $25^{\circ} \mathrm{C}$, using the model UV- $160 \mathrm{~A}$ spectrophotometer (Shimadzu, Japan). This enzyme assays were tested three times. Each experiment was replicated three times.

\section{Peroxidase (POD) activity}

Peroxidase (POD) activity was directly determined of the crude enzyme extract according to a typical procedure proposed by Hammerschmidt et al. (1982). Changes in absorbance at $470 \mathrm{~nm}$ were recorded every $30 \mathrm{sec}$ intervals for $3 \mathrm{~min}$. Enzyme activity was expressed as increase in absorbance $\mathrm{min}^{-1} \mathrm{~g}^{-1}$ fresh weight. Each experiment replicated three times.

\section{Polyphenol oxidase (PPO) activity}

Polypheno loxidase(PPO)enzyme assays in plants was prepared as described above in peroxidase (POD) activity assay. Activity of polyphenol oxidase (PPO) was determined according to the method described by Malik and Singh (1980). Changes in the absorbance at $495 \mathrm{~nm}$ were recorded every $30 \mathrm{sec}$ intervals for $3 \mathrm{~min}$. Enzyme activity was expressed as increase in absorbance min ${ }^{1} \mathrm{~g}^{-1}$ fresh weight. Each experiment was replicated three times.

\section{Determination of reactive oxygen species (ROS)}

For determining of reactive oxygen species (ROS), all the fresh leaves (fourth and fifth leaves) were collected at different time intervals (24, 48 and72 hrs) following inoculation. Superoxide $\mathrm{O}_{2}$ and hydrogen peroxide $\left(\mathrm{H}_{2} \mathrm{O}_{2}\right)$ were visualized as a purple coloration of nitro blue tetrazolium (NBT) and a reddishbrown coloration of 3, 3-diaminobenzidine (DAB), respectively. It was measured at different time intervals $(24,48$ and $72 \mathrm{hrs})$ following inoculation. Leaves of the susceptible (Giza 40), pretreated with $V$. lecanii and $T$. stipitatus were vacuum infiltrated with $10 \mathrm{mM}$ potassium phosphate buffer $(\mathrm{pH} 7.8)$ containing $0.1 \mathrm{w} / \mathrm{v} \%$ 
NBT (Sigma-Aldrich, Steinheim, Germany) according to Ádám et al. (1989) or $0.1 \mathrm{w} / \mathrm{v} \%$ DAB (Fluka, Buchs, Switzerland). NBT- and DAB-treated samples were incubated under daylight for $20 \mathrm{~min}$ and 2 hours, respectively and subsequently cleared in $0.15 \mathrm{w} / \mathrm{v} \%$ trichloroacetic acid in ethanol: chloroform 4:1 v/v for 1 day (Hückelhovenet al., 1999). Cleared samples were washed with water and placed in 50\% glycerol prior to evaluation. Discoloration of leaf discs were photographed and resulted by NBT or DAB staining was quantified using a Chemilmager 4000 digital imaging system (Alpha Innotech Corp., San Leandro, USA). This test was repeated three times. Uninfected leaves of susceptible cultivar Giza 40 were used as control (C1).In addition, non-pretreated infected FB leaves of both susceptible (Giza 40) and resistant (Sakha 2) cultivars were used also as control.

\section{Statistical analysis}

The experimental design was factorial in completely randomized design with four repetitions. The obtained data were subjected to analysis of variance according to Gomez and Gomez (1984). Treatment means were compared by Duncan's Multiple Range Test (Duncan,1955). All statistical analysis was performed using analysis of variance technique by means of "MSTATC" computer software package.

\section{RESULTS AND DISCUSSION}

\section{Effect of bio-inducer pretreatment on disease reduction}

Comparing with the untreated infected and untreated non-infected control, considerable reduction in DI and DS percentages were recorded when bio-agent inducers used to predispose FB plants to confront and control chocolate spot disease caused by $B$. fabae, as illustrated on Table 1 and 2. $T$. stipitatus and $V$. lecanii were superior in their effects by recording the lowest DI values of chocolate spot disease (Table1), while $T$. viride, was the less effective. Differences in DI \% between Nubaria 1 and Sakha 2 cvs were insignificant; however, their DI\% values were significantly lower, compared to untreated infected control (C2). Results of DI\% of infected controls shown in Table (1) confirmed that both Sakha 2 and Nubaria 1 cvs were resistant against the disease, where DI\% were 43.75 and $37.50 \%$, respectively, whereas Giza 40 was highly susceptible (DI\% was $81.25 \%$ ).

The same trend of DS values was noticed in Table (2)where differences between Sakha 2 (3.33\%) and Nubaria 1 (4.578\%) cvs were insignificant. However, DI\% values both of them were significantly lower than the susceptible Giza 40 (16.25\%). Differences in DS\% among the three tested bio-agent inducers treatments ( $V$. lecanii $T$. stipitatus \& $T$. viride) were insignificant within each cultivar. Moreover, Differences in mean values of DS\% among the tested bio-inducers were insignificant. Pretreatment with the tested bio-inducers before inoculation of the tested cvs with $B$. fabae resulted in sound significant reduction in DS\% values, compared to untreated inoculated control (C2). In addition, the highest reductions in DS\% in pretreated plants were detected in the resistant Sakha 2 and Noubaria $1 \mathrm{cvs}$. These findings were in harmony with results obtained by Haggag et al. (2006), who reported that T.flavus and $T$. harzianum reduced chocolate spot disease severity on FB. According to this study, lower disease severity values were recorded in plants pretreated with $T$. 
flavus and T. harzianumbio-inducers (1.2-6.4\% and 2.4-12,5\%, respectively, compared to control (32.6\%)(Ermias et al., 2013).

Table (1): Effect of treatment with the tested bioinducers on brown spot disease incidence (DI \%), in different faba bean cultivars.

\begin{tabular}{lcccc}
\hline \multirow{2}{*}{$\begin{array}{c}\text { Treatments } \\
\text { (T) }\end{array}$} & \multicolumn{4}{c}{ Disease Incidence (DI \%) } \\
\cline { 2 - 5 } & Giza 40 & Sakha 2 & Nubaria 1 & Average \\
\hline T. viride & $62.50 \mathrm{ab}$ & $25.00 \mathrm{cde}$ & $12.50 \mathrm{de}$ & $33.33 \mathrm{~B}$ \\
T. stipitatus & $31.25 \mathrm{~cd}$ & $31.25 \mathrm{~cd}$ & $18.75 \mathrm{cde}$ & $27.08 \mathrm{~B}$ \\
V. lecanii & $43.75 \mathrm{bc}$ & $37.50 \mathrm{bcd}$ & $37.50 \mathrm{bcd}$ & $39.58 \mathrm{~B}$ \\
C2 & $81.25 \mathrm{a}$ & $43.75 \mathrm{bc}$ & $37.50 \mathrm{bcd}$ & $54.17 \mathrm{~A}$ \\
C1 & $0.00 \mathrm{e}$ & $0.00 \mathrm{e}$ & $0.00 \mathrm{e}$ & $0.00 \mathrm{C}$ \\
Average & $43.75 \mathrm{~A}$ & $27.50 \mathrm{~B}$ & $21.25 \mathrm{~B}$ & \\
\hline LSD & $\mathbf{0 . 0 5}$ & $(\mathbf{T})=\mathbf{1 4 . 2}$ & \multicolumn{3}{c}{$\mathbf{C})=\mathbf{1 1 . 0 1 ( T \times ~ C ) = ~ 2 4 . 6 1}$} \\
\hline
\end{tabular}

Where: $\mathrm{C} 1=$ untreated non-inoculated control; $\mathrm{C} 2=$ untreated inoculated control; Giza $40=$ susceptible cultivar; and Sakha2 and Nubaria $1=$ resistant cultivars; and T. viride, $T$. stipitatus and $V$. lecanii= Bio-agent inducers.

Table (2): Effect of treatment with the tested bioinducers on brown spot disease severity (DS \%), in different faba bean cultivars.

\begin{tabular}{|c|c|c|c|c|}
\hline \multirow{3}{*}{$\begin{array}{c}\text { Treatments } \\
\text { (T) }\end{array}$} & \multicolumn{4}{|c|}{ Disease Severity DS\% } \\
\hline & \multicolumn{4}{|c|}{ Cultivars ( C ) } \\
\hline & Giza 40 & Sakha 2 & Nubaria 1 & Average \\
\hline T. viride & $9.028 \mathrm{c}$ & $2.777 \mathrm{~d}$ & $1.390 \mathrm{~d}$ & $4.398 B$ \\
\hline T. stipitatus & $5.555 \mathrm{~cd}$ & $4.863 \mathrm{~cd}$ & $2.085 \mathrm{~d}$ & $4.168 \mathrm{~B}$ \\
\hline V. lecanii & $4.170 \mathrm{~cd}$ & $4.170 \mathrm{~cd}$ & $4.170 \mathrm{~cd}$ & $4.170 \mathrm{~B}$ \\
\hline $\mathrm{C2}$ & $62.50 \mathrm{a}$ & $4.863 \mathrm{~cd}$ & $15.24 b$ & $27.54 \mathrm{~A}$ \\
\hline C1 & $0.00 \mathrm{~d}$ & $0.00 \mathrm{~d}$ & $0.00 \mathrm{~d}$ & $0.00 \mathrm{C}$ \\
\hline Average & $16.25 \mathrm{~A}$ & $3.335 \mathrm{~B}$ & $4.578 \mathrm{~B}$ & \\
\hline LSD $_{0.05}$ & (1) & 88 & 2.315(T x C & 176 \\
\hline
\end{tabular}

Where: $\mathrm{C} 1=$ untreated non-inoculated control; $\mathrm{C} 2=$ treated inoculated control; Giza $40=$ susceptible cultivar; and Sakha2 and Nubaria 1= resistant cultivars; and $T$. viride, $T$. stipitatus and $V$. lecanii= Bioagent inducers.

These observations on the effect of pretreatments with bio-inducers on DS\% of both susceptible (Giza 40) and resistant (Sakha 2) cvs proved that various responses towered reduction of DI and DS\%. Moreover, current findings revealed that $V$. lecanii and $T$. stipitatus were more efficient in reducing $D I$ and DS than T. viride, similar results were obtained by El-Komy (2014) on the reactions of the two FB cultivars expressing different levels of resistance 
against to $B$. fabae, Nubaria (resistant) and Giza 40 (susceptible) cultivars, using whole plant assays to avoid responses induced by wounding and not associated with the infection. For both cultivars, there was significant increase in disease severity over time. The progress of the disease symptoms evolved slowly on resistant cultivar but occurred at a much greater rate on the susceptible cultivar. However, disease severity was significantly lower for Nubaria cv than for Giza $40 \mathrm{cv}$, regardless of the time elapsed after inoculation. These results were in agreement with those of Abo-Hegazy et al. (2012), who confirmed the resistance of Nubaria cv and the susceptibility of Giza $40 \mathrm{cv}$. to infection by $B$. fabae. The lowest levels of disease severity recorded in the leaves of Nubaria 1 and Sakha 2 cvssuggest that resistance events that delay tissue colonization after fungal infection play a role in the FB $\times B$. fabae interaction (Hanounik and Maliha, 1986, and Hanounik and Robertson, 1988).

\section{Effect of pretreatment on oxidative enzymes activity: Peroxidase activity (POD)}

Results recorded in Table 3 showed that peroxidase activity values significantly affected according to the tested cultivar, bio-inducer and time elapsed after inoculation. Pretreatment of faba bean plants with the tested bioinducers before inoculation with $B$. faba resulted in insignificant changes in POD enzyme activities during the first day after inoculation (Table 3). Moreover, differences in POD activity values among all the tested treatments during the first 24 hours period after inoculation were insignificant.

After 48 hours of inoculation, sound significant differences in POD activities were detected in both resistant (Sakha 2) and susceptible (Giza 40) faba bean cultivars, pretreated with the tested $T$. stipitatus bio-inducer, compared with untreated non inoculated (C1) and inoculated (C2) control. Moreover, increase in POD activities was significantly higher in resistant Sakha $2 \mathrm{cv}$ than susceptible Giza $40 \mathrm{cv}$ (0.1997 and 0.1245, respectively). Pretreatment with the bio-inducer $V$. lecanii resulted in insignificant differences in POD activities throughout all the tested periods, compared with control. According to the mean values of POD activities of the three tested time periods, pretreatment with $T$. stipitatus significantly increased POD activities in both resistant and susceptible cvs (0.0573 and 0.0800, respectively); however, differences between the two bio-inducers were insignificant.

Therefore, according to data recorded in Table 3, it could be concluded that the bio-inducer $T$. stipitatus proved to be effective in increasing POD activities in both tested resistant and susceptible cvs during the second day after inoculation. Moreover, increase in POD activitiies induced by $T$. stipitatus two days after inoculation was higher in the resistant than the susceptible cv.

Our findings indicate the positive relationship between resistance of faba bean against chocolate leaf spots and peroxidase activity. These findings were in line with those reported by Ride (1983) and Tarrad et al. (1993), who found that increase in peroxidase activity enhance lignification in response to chocolate spot infection which may restrict the fungal penetration. Moreover, Nawar and Kuti (2003) concluded that peroxidase activity is considered as a preliminary indicator for resistance of broad beans to chocolate spot disease. 
Table (3): Changes in peroxidase enzyme (POD) activities in resistant and susceptible faba bean cultivars pretreated with the tested bioagent inducers and inoculated with $B$. fabaeat different periods following inoculation.

\begin{tabular}{|c|c|c|c|c|c|}
\hline \multirow{3}{*}{$\begin{array}{l}\text { Cultivars } \\
\text { (C) }\end{array}$} & \multirow{3}{*}{$\begin{array}{l}\text { Treatments } \\
\text { (T) }\end{array}$} & \multicolumn{4}{|c|}{$\begin{array}{c}\text { Peroxidase activity } \\
\text { (absorbance } \operatorname{~in~}^{-1} \mathrm{~g}^{-1} \text { fresh weight) }\end{array}$} \\
\hline & & \multicolumn{4}{|c|}{ Time after inoculation (P) } \\
\hline & & 24 hrs & $48 \mathrm{hrs}$ & $72 \mathrm{hrs}$ & Average \\
\hline & & \multicolumn{3}{|c|}{$C \times T \times P$ - average } & C x T- average \\
\hline \multirow[t]{4}{*}{ Giza40 } & C1 & $0.0052 \mathrm{c}$ & $0.0168 \mathrm{c}$ & $0.0173 \mathrm{c}$ & $0.0131 \mathrm{~B}$ \\
\hline & $\mathrm{C} 2$ & $0.0147 \mathrm{c}$ & $0.0103 \mathrm{c}$ & $0.0061 \mathrm{c}$ & $0.0104 \mathrm{~B}$ \\
\hline & T. stipitatus & $0.0276 \mathrm{c}$ & $0.1245 \mathrm{~b}$ & $0.0198 \mathrm{c}$ & $0.0573 \mathrm{~A}$ \\
\hline & V. lecanii & $0.0271 \mathrm{c}$ & $0.0207 \mathrm{c}$ & $0.0130 \mathrm{c}$ & $0.0203 \mathrm{~B}$ \\
\hline \multirow[t]{4}{*}{ Sakha2 } & C1 & $0.0102 \mathrm{c}$ & $0.0173 \mathrm{c}$ & $0.0111 \mathrm{c}$ & $0.0129 \mathrm{~B}$ \\
\hline & & $0.0138 c$ & $0.0152 \mathrm{c}$ & $0.0041 \mathrm{c}$ & $0.011 \mathrm{~B}$ \\
\hline & T. stipitatus & $0.0086 \mathrm{c}$ & $0.1997 \mathrm{a}$ & $0.0316 \mathrm{c}$ & $0.08 \mathrm{~A}$ \\
\hline & V. lecanii & $0.0216 \mathrm{c}$ & $0.0078 \mathrm{c}$ & $0.0069 \mathrm{c}$ & $0.0121 \mathrm{~B}$ \\
\hline \multirow{2}{*}{ LSD $_{0.05}$} & & & 0.0519 & & 0.0299 \\
\hline & & \multicolumn{3}{|c|}{ C X P - average } & C- average \\
\hline Giza40 & & $0.0186 \mathrm{~b}$ & $0.0431 \mathrm{a}$ & $0.0140 \mathrm{~b}$ & 0.0253 \\
\hline Sakha2 & & $0.0135 \mathrm{~b}$ & $0.0600 \mathrm{a}$ & $0.0134 \mathrm{~b}$ & 0.029 \\
\hline \multirow[t]{6}{*}{ LSD $_{0.05}$} & & & 0.022 & & NS \\
\hline & & \multicolumn{3}{|c|}{$T \times P-$ average } & T- average \\
\hline & C1 & $0.0077 \mathrm{~b}$ & $0.0171 \mathrm{~b}$ & $0.0142 \mathrm{~b}$ & $0.013 \mathrm{~B}$ \\
\hline & $\mathrm{C} 2$ & $0.0142 \mathrm{~b}$ & $0.0128 \mathrm{~b}$ & $0.0051 \mathrm{~b}$ & $0.0107 \mathrm{~B}$ \\
\hline & T. stipitatus & $0.0181 \mathrm{~b}$ & $0.1621 \mathrm{a}$ & $0.0257 \mathrm{~b}$ & $0.0687 \mathrm{~A}$ \\
\hline & V. lecanii & $0.0244 \mathrm{~b}$ & $0.0142 b$ & $0.0099 \mathrm{~b}$ & $0.0162 \mathrm{~B}$ \\
\hline LSD $_{0.05}$ & & & 0.0367 & & 0.021 \\
\hline \multicolumn{2}{|c|}{$P$ - average } & $0.0161 \mathrm{~B}$ & $0.0515 \mathrm{~A}$ & $0.0137 \mathrm{~B}$ & \\
\hline $\operatorname{LSD}_{0.05}$ & & & 0.0184 & & \\
\hline
\end{tabular}

Where: $\mathrm{C} 1=$ untreated non-inoculated control; $\mathrm{C} 2=$ untreated inoculated control; Giza $40=$ susceptible cultivar; and Sakha2 and Nubaria 1= resistant cultivars; and T. viride, T. stipitatus and $V$. lecanii= Bioagent inducers.

Data obtained throughout this investigation showed the positive role of bio-inducers, inparticular T. stipitatusin decreasing disease severity and enhancement of peroxidase activity, and hence induction of resistance. The role of oxidative enzymes such as peroxidase could be explained as an oxidation process of phenol compounds to oxidized products (quinones) which may limit the fungal growth (Vance et al., 1980, and Tarradet al., 1993), oxidation of polymerization of hydroxycinnamyl alcohols to yield lignin (Fry, 1982, and Cvikrová et al., 2006), production of free radicals and hydrogen peroxide which are toxic to many microorganisms (Peng and Kuc, 1992), and makes the cell wall more mechanically rigid by cross-linking matrix polysaccharide and glycoprotein molecules and consequently inhibit cell wall degrading enzymes of the pathogen (El-Komy et al., 2015). 


\section{Polyphenol oxidase (PPO) activity}

Pretreatment of faba bean plants of resistant cv Sakha 2 with $T$. stipitatus and $V$. lecanii resulted inpronounced increase of PPO enzyme activities after 24 hrs of inoculation ( 0.0226 and 0.0087 , respectively) (Table 4), compared to inoculated control (C2) (0.0060). Moreover, enzyme activity was much higher in $T$. stipitatus pretreatment than that of $V$. lecanii. Meanwhile, differences in enzyme activity between susceptible Giza $40 \mathrm{cv}$ and infected control were insignificant during the first $24 \mathrm{hrs}$ after inoculation. After the second day of inoculation, significant increase in PPO activities in susceptible cv, pretreated with $T$. stipitatus and $V$. lecanii, compared with control, however, increase was higher in $V$. lecanii treatment $(0.0040$ and 0.0275 , respectively). On the other hand, T. stipitatus was more effective in increasing PPO activities (0.0050), whereas PPO activity in $V$. lecanii treatment was insignificant, compared to the other tested treatments.

After 72 hrs of inoculation, differences in PPO activity values between bio-inducer-pretreated Giza 40 plants and control were insignificant. However, pretreatment of resistant Sakha 2 plants with $T$. stipitatus significantly increased PPO activities, compared to control. These results suggest that the expression of phenoloxidizing enzymes can be associated with the resistance to $B$. fabae. Nawar and Kuti (2003) also reported that PO activity could be used as a biomarker to evaluate the resistance reactions in FB plants against chocolate spot disease.

Peroxidase and polyphenol oxidase catalyzes the oxidation of phenolic compounds to quinones (antimicrobial compounds) (El Komy et al., 2015), involved in IAA biosynthesis Endogenous reactive oxygen species (ROS) such as superoxide $\left(\mathrm{O}_{2}{ }^{-}\right)$and hydrogen peroxide $\left(\mathrm{H}_{2} \mathrm{O}_{2}\right)$ were stimulated significantly early after natural infection consequently, later on activities of catalase (CAT), peroxidase (POX) and poly phenol oxidase (PPO) were significantly increased compared with the control(Hafez et al., 2014).

\section{Effect of pretreatment on ROS production Level of Hydrogen peroxide $\left(\mathrm{H}_{2} \mathrm{O}_{2}\right)$}

The obtained data of Table 5 and Figure 1 showed that the activities of hydrogen peroxide $\left(\mathrm{H}_{2} \mathrm{O}_{2}\right)$ varied significantly according to the tested bio-inducer and time elapsed after inoculation. Generally, according to the mean values of $\mathrm{H}_{2} \mathrm{O}_{2}$ of each time interval, it was evident that the lowest $\mathrm{H}_{2} \mathrm{O}_{2}$ level (15.58) was obtained directly after inoculation, increased by time, reaching maximum levels 72 after inoculation (31.01). 
Table (4): Changes in polyphenol oxidase enzyme (PPO) activities in resistant and susceptible faba bean cultivars, pretreated with the tested bioagent inducers and inoculated with $B$. fabaeat different periods following inoculation.

\begin{tabular}{|c|c|c|c|c|c|}
\hline \multirow{3}{*}{$\begin{array}{l}\text { Cultivars } \\
\text { (C) }\end{array}$} & \multirow{3}{*}{$\begin{array}{l}\text { Treatments } \\
\text { (T) }\end{array}$} & \multicolumn{4}{|c|}{$\begin{array}{c}\text { Polyphenol oxidase activity } \\
\text { (absorbance } \mathrm{min}^{-1} \mathrm{~g}^{-1} \text { fresh weight) }\end{array}$} \\
\hline & & \multicolumn{3}{|c|}{ Time after inoculation ( $p)$} & \\
\hline & & 24 hrs & $48 \mathrm{hrs}$ & 72 hrs & Average \\
\hline & & \multicolumn{3}{|c|}{ C X T X P-average } & C x T- average \\
\hline \multirow[t]{4}{*}{ Giza40 } & C1 & $0.0087 \mathrm{bc}$ & $0.00193 \mathrm{c}$ & $0.0030 \mathrm{c}$ & $0.0045 \mathrm{~B}$ \\
\hline & $\mathrm{C} 2$ & $0.0012 \mathrm{c}$ & $0.0013 \mathrm{c}$ & $0.0044 \mathrm{bc}$ & $0.0022 \mathrm{~B}$ \\
\hline & T. stipitatus & $0.0010 \mathrm{c}$ & $0.0040 \mathrm{bc}$ & $0.0020 \mathrm{c}$ & $0.0023 \mathrm{~B}$ \\
\hline & V. lecanii & $0.0025 \mathrm{c}$ & $0.0275 \mathrm{a}$ & $0.0010 \mathrm{c}$ & $0.0103 \mathrm{AB}$ \\
\hline \multirow[t]{4}{*}{ Sakha2 } & $\mathrm{C} 1$ & $0.0030 \mathrm{c}$ & $0.0025 \mathrm{c}$ & $0.0025 \mathrm{c}$ & $0.0027 \mathrm{~B}$ \\
\hline & & $0.0060 \mathrm{bc}$ & $0.0016 \mathrm{c}$ & $0.0036 \mathrm{bc}$ & $0.00381 \mathrm{~B}$ \\
\hline & T. stipitatus & $0.0226 \mathrm{ab}$ & $0.0050 \mathrm{bc}$ & $0.0040 \mathrm{bc}$ & $0.0105 \mathrm{AB}$ \\
\hline & V. lecanii & $0.0087 \mathrm{bc}$ & $0.0019 \mathrm{c}$ & $0.0030 c$ & $0.0045 \mathrm{~B}$ \\
\hline \multirow{2}{*}{$\mathbf{L S D}_{0.05}$} & & & 0.00164 & & 0.009 \\
\hline & & \multicolumn{3}{|c|}{ C X P - average } & C- average \\
\hline Giza40 & & $0.0069 \mathrm{~b}$ & $0.0057 \mathrm{c}$ & $0.0053 \mathrm{c}$ & 0.0060 \\
\hline Sakha2 & & $0.0085 \mathrm{a}$ & $0.0092 \mathrm{a}$ & $0.0028 d$ & 0.0068 \\
\hline \multirow[t]{6}{*}{$\mathbf{L S D}_{0.05}$} & & & 0.0009 & & NS \\
\hline & & \multicolumn{3}{|c|}{ T $\times P$ - average } & T- average \\
\hline & $\mathrm{C} 1$ & $0.0098 \mathrm{ab}$ & $0.0218 \mathrm{a}$ & $0.0065 \mathrm{~b}$ & $0.0127 \mathrm{~A}$ \\
\hline & $\mathrm{C} 2$ & $0.0058 \mathrm{~b}$ & $0.0022 \mathrm{~b}$ & $0.0027 \mathrm{~b}$ & $0.0036 \mathrm{~B}$ \\
\hline & T. stipitatus & $0.0036 \mathrm{~b}$ & $0.0013 \mathrm{~b}$ & $0.0040 \mathrm{~b}$ & $0.0029 \mathrm{~B}$ \\
\hline & V. lecanii & $0.0118 \mathrm{ab}$ & $0.0045 \mathrm{~b}$ & $0.0030 \mathrm{~b}$ & $0.0064 \mathrm{AB}$ \\
\hline LSD $_{0.05}$ & & & 0.0116 & & 0.006 \\
\hline \multicolumn{2}{|l|}{$P$ - averaqe } & $0.0077 \mathrm{~A}$ & $0.0071 \mathrm{~A}$ & $0.0041 \mathrm{~b}$ & \\
\hline LSD $_{0.05}$ & & & 0.0018 & & \\
\hline
\end{tabular}

Where: $\mathrm{C} 1=$ untreated non-inoculated control; $\mathrm{C} 2=$ untreated inoculated control; Giza $40=$ susceptible cultivar; and Sakha2 and Nubaria 1= resistant cultivars; and T. viride, T. stipitatus and $V$. lecanii= Bioagent inducers.

Table (5): level of hydrogen peroxide $\left(\mathrm{H}_{2} \mathrm{O}_{2}\right)$ in faba bean resistant and susceptible cultivars pretreated with the tested bio-agent inducers and inoculated with $B$. fabae at different periods following inoculation.

\begin{tabular}{|c|c|c|c|c|}
\hline \multirow{3}{*}{$\begin{array}{c}\text { Treatments } \\
(\mathrm{T})\end{array}$} & \multicolumn{4}{|c|}{ Level of hydrogen peroxide $\left(\mathrm{H}_{2} \mathrm{O}_{2}\right)$ Arbitrary units } \\
\hline & \multicolumn{4}{|c|}{ Time after inoculation $(\mathbf{P})$} \\
\hline & 24 hrs & $48 \mathrm{hrs}$ & $72 \mathrm{hrs}$ & Average \\
\hline $\mathrm{C} 1$ & $11.16 \mathrm{e}$ & $18.51 \mathrm{de}$ & $24.67 \mathrm{bcd}$ & $18.11 \mathrm{C}$ \\
\hline $\mathrm{C} 2$ & $24.24 \mathrm{bcd}$ & $24.45 \mathrm{bcd}$ & $39.21 \mathrm{a}$ & $29.30 \mathrm{~A}$ \\
\hline C3 & $14.59 \mathrm{e}$ & $25.11 \mathrm{bcd}$ & $32.82 \mathrm{ab}$ & 24.17 B \\
\hline T.stipitatus & $14.32 \mathrm{e}$ & 20.04 cde & $30.40 \mathrm{~b}$ & $21.58 \mathrm{BC}$ \\
\hline V. lecanii & $13.59 \mathrm{e}$ & 19.82 cde & $27.97 \mathrm{bc}$ & $20.46 \mathrm{BC}$ \\
\hline Average & $15.58 \mathrm{C}$ & $21.58 \mathrm{~B}$ & $31.01 \mathrm{~A}$ & \\
\hline $\mathbf{L S D}_{0.05}$ & $T=4.56$ & $P=3.53$ & $\mathbf{T X} \mathbf{P =}$ & \\
\hline
\end{tabular}

Where: $\mathrm{C} 1=$ untreated non-inoculated control of susceptible cv Giza 40; C2= untreated inoculated control of Giza 40; C3= untreated inoculated control of resistant cv Sakha 2, T. stipitatus and $V$. lecanii= bioagent inducers. 


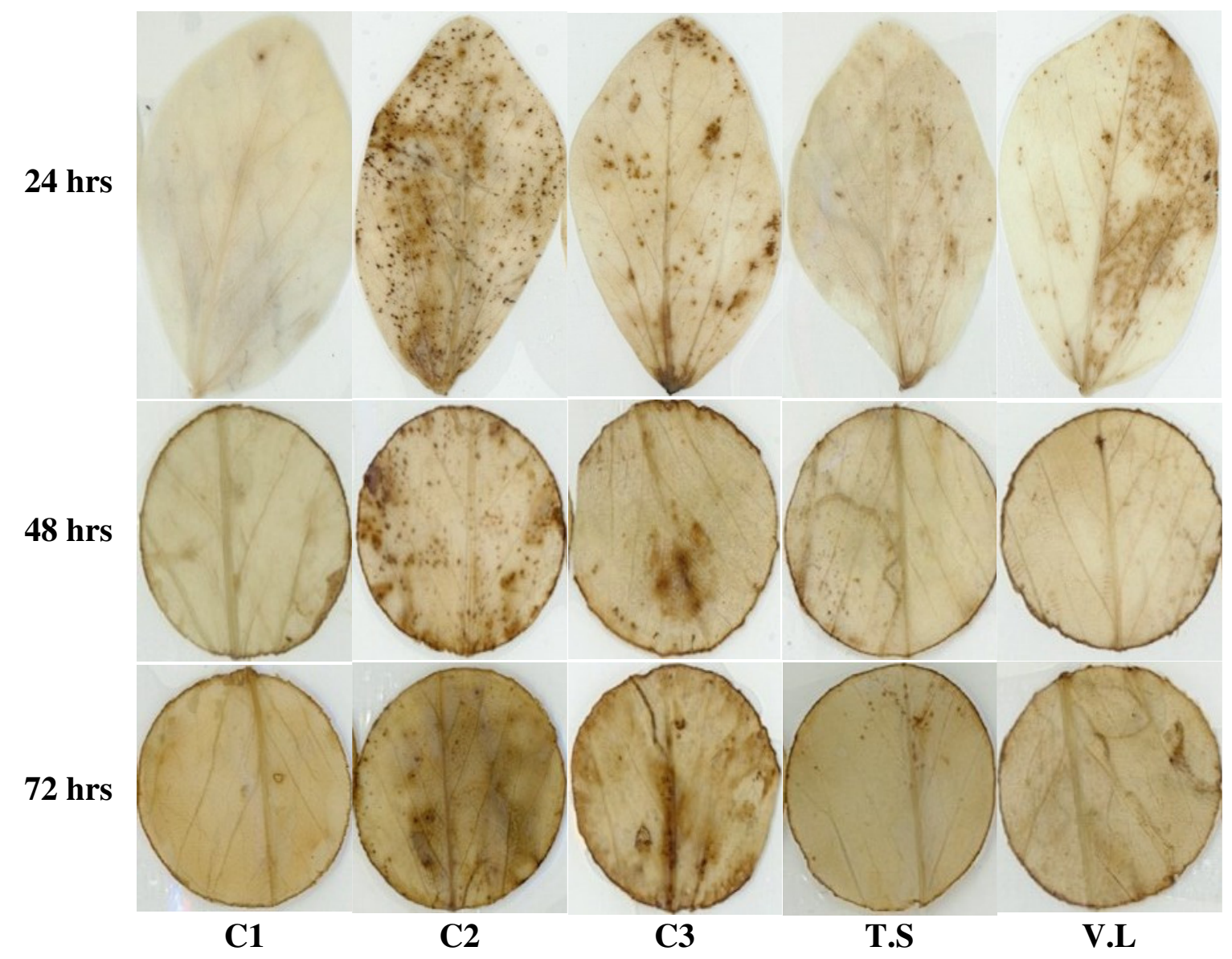

Figure (1): Brown discoloration (using DBA pigment) of hydrogen peroxide $\left(\mathrm{H}_{2} \mathrm{O}_{2}\right)$ in both resistant and susceptible faba bean cultivars pre-treated with the tested bio-agent inducers and inoculated with $B$. fabaeat different periods following inoculation.

Where: $\mathrm{C} 1=$ untreated non-inoculated control of susceptible cv Giza 40; $\mathrm{C} 2=$ untreated inoculated control of Giza 40; C3= untreated inoculated control of resistant cv Sakha 2, T. stipitatus and $V$. lecanii= bioagent inducers.

This was true in both untreated inoculated controls of both resistant and susceptible cvs ( $\mathrm{C} 1$ and $\mathrm{C} 2$ ) and inoculated plants pretreated with the tested bioinducers. Differences in $\mathrm{H}_{2} \mathrm{O}_{2}$ levels between the two tested bio-inducers $T$. stipitatus and $V$. lecanii during the three tested time periods were statistically insignificant. Hydrogen peroxide levels were higher in untreated inoculated control of susceptible Giza $40 \mathrm{cv}$ (C2), compared to that of resistant Sakha $2 \mathrm{cv}$ (C3), particularly in the first and third tested time periods (Table 6 and Figure1).

The obtained results indicated that the oxidative burst activities, which significantly varied among FB cultivars, are considered an essential process in defence mechanism. The higher levels of ROS accumulation were positively correlated with susceptibility of FB leaf tissues to infection with the necrotrophic fungus $B$. fabae, and significantly varied in intensity and induction timing according toFB resistance levels. These findings assured conclusions of many 
published papers (von Tiedemann, 1997, Govrin and Levine, 2000, Mayer et al., 2001 and Schouten et al., 2002)

Moreover, pretreatment with the tested bio-inducers, T. stipitatus and $V$. lecanii, significantly increased the ROS level early, as a result, induction of the antioxidants occurred later, and accordingly the fungal growth was suppressed. These conclusions were in agreement with those reported by El-Komy (2014), who demonstrated that the accumulation of these defense responses was induced significantly in both cultivars upon infection with $B$. fabae compared with non-inoculated controls. He also found that resistant cultivar showed weaker necrotic symptom expression, less ROS accumulation, a lower rate of lipid peroxidation and higher activity of the enzymatic ROS scavenging system compared with susceptible cultivar.

In the present study, a significant increase in $\mathrm{H}_{2} \mathrm{O}_{2}$ generation in both $\mathrm{FB}$ cultivars was observed in response to $B$. fabae inoculation, compared with noninoculated plants. Moreover, the greatest accumulation of $\mathrm{H}_{2} \mathrm{O}_{2}$ detected in the susceptible cultivar Giza 40, indicated that production of higher levels of ROS is positively correlated to the susceptibility of FB leaf tissues to infection with $B$. fabae. These findings confirmed the findings of many researchers (GarciaLimones et al., 2002, Mellersh et al., 2002, and El-Komy, 2014). However, Govrin and Levine (2000) and Shi et al. (2011) showed that the inoculation of $B$. cinerea induced an oxidative burst in Arabidopsis, and the aggressiveness of this pathogen was directly dependent on the level of ROS accumulation. As a result of early stimulation of ROS, disease severity (\%) and disease symptoms were suppressed. This perhaps attributed to the inhibiting or killing action of ROS to the fungal pathogen early after infection, therefore, there was no chance for the pathogen to grow or propagate (El-Zahaby et al., 2004, Hafez, 2010, and Hafez et al., 2014).

\section{Level of superoxide $\left(\mathrm{O}_{2}{ }^{--}\right)$using (NBT)}

Data in Table 6 and Figure 2 showed significant increase in Levels of superoxide $\left(\mathrm{O}_{2}{ }^{-}\right)$in untreated non inoculated faba bean plants of susceptible $\mathrm{cv}$ at the first and second day periods (38.33), however, significant drop was detected after the second and third day periods (14.76 and 27.55 , respectively).

Pretreatment with $T$. stipitatus significantly reduced $\mathrm{O}_{2}{ }^{--}$level after $24 \mathrm{hrs}$ of inoculation (14.10), compared to control, however, $\mathrm{O}_{2}{ }^{--}$levels gradually increased to reach maximum values (35.24) after the third day period. On the other hand, $\mathrm{O}_{2}{ }^{--}$level in $\mathrm{V}$. lecanii treatment showed significant increase after the first day (23.13), sudden drop after the second day (17.84), and then reaching maximum levels $72 \mathrm{hrs}$ after inoculation (26.44). According to Figure(1\&2), $\mathrm{H}_{2} \mathrm{O}_{2}$ and $\mathrm{O}_{2}{ }^{--}$ levels were decreased due to the effect of pretreatment with both of the tested bio-inducers.

According to $\mathrm{O}_{2}{ }^{--}$level mean values of the three tested periods, $\mathrm{O}_{2}{ }^{--}$level in $T$. stipitatus treatment was higher than that of $V$. lecanii $(24,01$ and 22.47 , respectively). Moreover, maximum levels of $\mathrm{O}_{2}{ }^{-}$were obtained $72 \mathrm{hrs}$ after inoculation (Table 6and Figure2). The results of the present investigation indicated that the bio-inducers pretreatments increased the ROS level early within 72 hrs after inoculation, as a result, induction of the antioxidants was occurred later, and accordingly the fungal growth was suppressed. 
These results were in great similarity with those obtained by Hafez et al. (2014), who concluded that the endogenous reactive oxygen species (ROS) such as superoxide $\left(\mathrm{O}_{2}{ }^{-}\right)$and hydrogen peroxide $\left(\mathrm{H}_{2} \mathrm{O}_{2}\right)$ were stimulated significantly early after natural infection consequently, later on activities of catalase (CAT), peroxidase (POX) and poly phenol oxidase (PPO) were increased significantly compared with the control. Mohamed et al. (2007) and Mohamed, et al. (2012) reported that peroxidase has different functions in different defense mechanisms.

Table (6): level of superoxide $\left(\mathrm{O}_{2}-\right.$ ) by using NBT in faba bean resistant and susceptible cultivars pretreated with the tested bio-agent inducers and inoculated with $B$. fabae at different periods following inoculation.

\begin{tabular}{|c|c|c|c|c|}
\hline \multirow{3}{*}{$\begin{array}{c}\text { Treatments } \\
\text { ( T) }\end{array}$} & \multicolumn{4}{|c|}{ Level of Superoxide $\left(\mathrm{O}_{2}{ }^{-}\right)$Arbitrary units } \\
\hline & \multicolumn{4}{|c|}{ Time after inoculation (P) } \\
\hline & 24 hrs & $48 \mathrm{hrs}$ & 72 hrs & Average \\
\hline $\mathrm{C} 1$ & $38.33 \mathrm{a}$ & 27.55 cde & $14.76 \mathrm{i}$ & $26.88 \mathrm{~A}$ \\
\hline $\mathrm{C} 2$ & 16.52 hi & 25.33 def & $28.20 \mathrm{~cd}$ & $23.35 \mathrm{BC}$ \\
\hline C3 & 25.77 cde & $20.48 \mathrm{fgh}$ & $30.83 \mathrm{bc}$ & $25.69 \mathrm{AB}$ \\
\hline T. stipitatus & $14.10 \mathrm{i}$ & 22.69 efg & $35.24 a b$ & $24.01 \mathrm{ABC}$ \\
\hline V. lecanii & 23.13 def & $17.84 \mathrm{ghi}$ & 26.44 cde & $22.47 \mathrm{C}$ \\
\hline Average & 23.57 B & $22.78 \mathrm{~B}$ & $27.09 \mathrm{~A}$ & \\
\hline LSD $_{0.05}$ & $\mathrm{~T}=2.752$ & $p=2.131$ & $\mathrm{~T} \times \mathrm{p}=4$ & \\
\hline
\end{tabular}

Where: $C 1=$ untreated non-inoculated control of susceptible cv Giza 40; C2= untreated inoculated control of Giza 40; C3= untreated inoculated control of resistant cv Sakha 2, $T$. stipitatus and $V$. lecanii= bioagent inducers. 


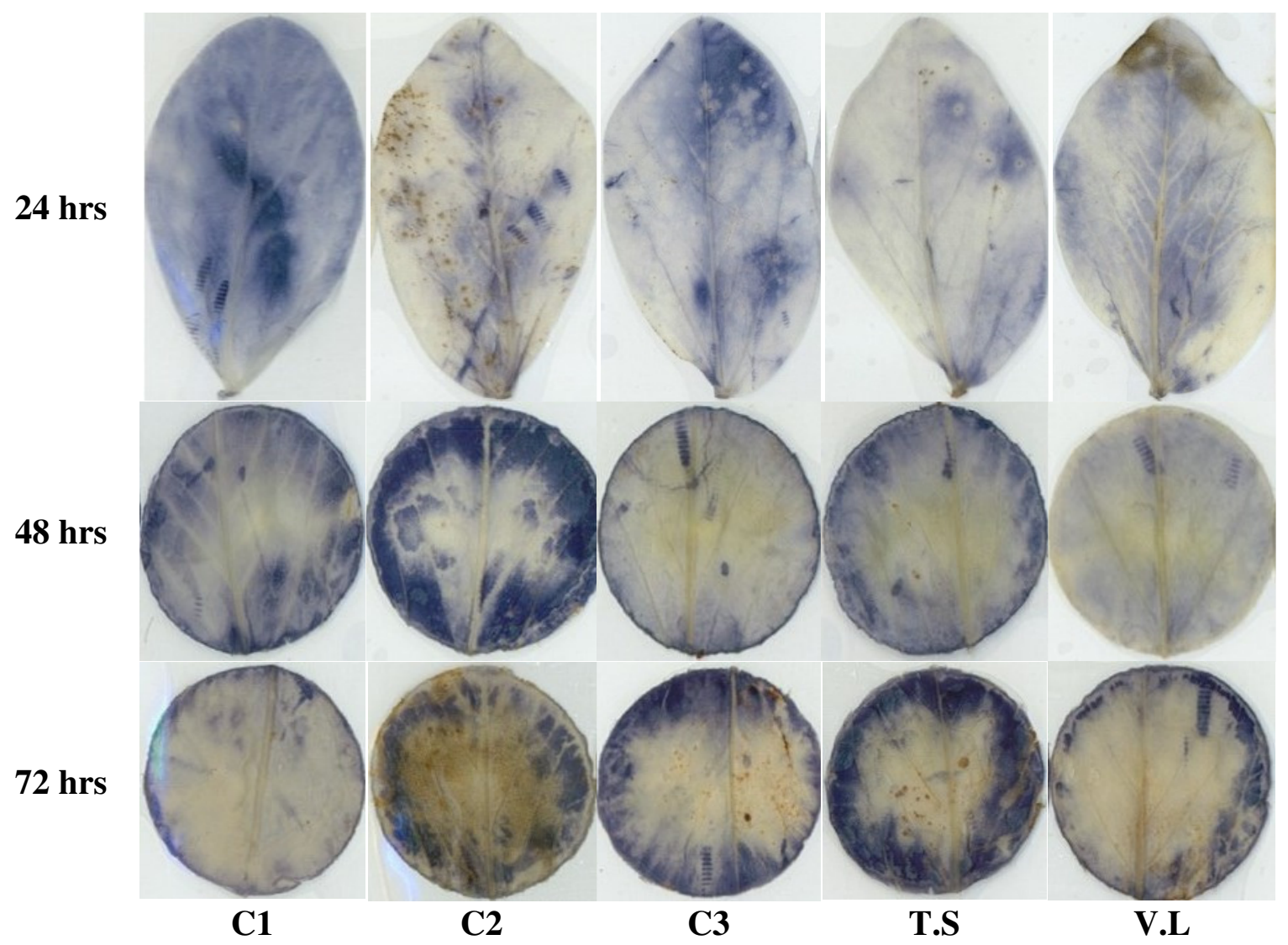

Figure (2): Purple discoloration (using NBT pigment) of superoxide $\left(\mathrm{O}_{2}^{-}\right)$ in both resistant and susceptible faba bean cultivars pretreated with the tested bio-agent inducers and inoculated with $B$. fabae at different periods following inoculation.

Where: $C 1=$ untreated non-inoculated control of susceptible cv Giza 40; $C 2=$ untreated inoculated control of Giza 40; C3= untreated inoculated control of resistant cv Sakha 2, T. stipitatus and $V$. lecanii= bioagent inducers.

\section{REFERENCES}

Abd El-Rahman, S.S. and H. I. Mohamed.(2014). Application of benzothiadiazole and Trichodermaharzianum to control faba bean chocolate spot disease and their effect on some physiological and biochemical traits. Acta Physiol. Plant, 36: 343-354.

Abo-Hegazy, S.R.E., N.F. El-Badawy, M.M. MazenandH. Abd El-Menem (2012). Evaluation of some faba bean genotypes against chocolate spot disease using cDNA fragments of chitinase gene and some traditional methods.Asian J. Agric. Res., 6:60-72.

Abou-Zeid, N.M., M.S.H., Moustafa, A.M. Hassanien and I. Ez-El-Din (1990).Control of chocolate spot disease of faba bean and the effect of fungicides on the behavior of the causal fungus. Agric. Res. Rev.,68:411421.

Ádám, A., T. Farkas,G. Somlyai, M. Hevesi and Z. Király. (1989).

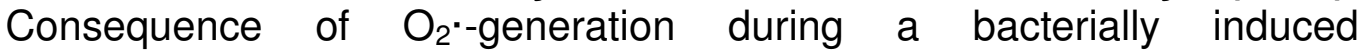


hypersensitive reaction in tobacco: deterioration of membrane lipids. Physiol. Mol. Plant Pathol., 34:13-26.

ApelK., and H.Hirt. (2004). Reactive oxygen species: metabolism, oxidative stress, and signal transduction. AnnuRev. Plant Biol.,55:373-399.

Asselbergh, B.K., Curvers, S.C.Franca, K.Audenaert, M.Vuylsteke, F.V. Breusegem and M.Höfte. (2007). Resistance to Botrytis cinerea in sitiens, an abscisic acid-deficient tomato mutant, involves timely production of hydrogen peroxide and cell wall modifications in the epidermis. Plant Physiol.,144:1863-1877.

Bernier, C.C., S.B.Hanounik, M.M.Hussein and H.A. Mohamed. (1984). Rating scale for faba bean diseases in Nile valley. ICARDA Information Bulletin,3:37.

Bernier,C.C., S.B. Hanounik, M.M. Hussein and H.A. Mohamed. (1993). Field manual of common faba bean diseases in the Nile Valley. International Center for Agricultural Research in the Dry Areas ICARDA) information Bulletin,3.

Bolwell,P.G.,L.V.Bindschedler,K.A.Blee,V.S.Butt,D.R.Davies,S.L.Gardner,C .Gerrishand F. Minibayeva. (2002). The apoplastic oxidative burst in response to biotic stress in plants: a three component system. J. Exp. Bot.,53:1367-1376.

Bouhassan, A., Sadiki, M., and B.Tivoli. (2004). Evaluation of a collection of faba bean (Viciafabae L.) genotypes originating from the Maghreb for resistance to chocolate spot (Botrytis fabae) by assessment in the field and laboratory. Euphytica 135:55-62.

Bradley D.J., P. Kjellbomand C.J. Lamb. (1992). Elicitor- and wound-induced oxidative crosslinking of a proline-rich plant cell wall protein, a novel, rapid defence response. Cell,70:21-30.

Cvikrová, M., J.Malá, M.Hrubcová and J. Eder. (2006). Soluble and cell wallbound phenolics and lignin in Ascocalyxabietina infected Norway spruces. Plant Sci., 170:563-570.

Dangl, J. andJ. D. G. Jones. (2001). Plant pathogens and integrated defense responses to pathogens. Nature,411:826-834.

Duncan, D.B.(1955).Multiple range and multiple f-tests.Biometrcs, 11:1-42.

El-Hendawy, S., W.Shaban and J. Sakagami. (2010). Does treating faba bean seeds with chemical inducers simultaneously increase chocolate spot disease resistance and yield under field conditions. Turk. J. Agri., 34:475485.

El-Komy, H.M.(2014). Comparative analysis of defense responses in chocolate spot-resistant and -susceptible fababean (Viciafaba) cultivars following infection by the necrotrophicfungus Botrytis fabae. Plant Pathol. J., 30(4):355-366.

El-Komy, M.H., A.A.Saleh. and Y.Y. Molan. (2015). Resistance and susceptibility of faba bean to Botrytis fabae: the causal agent of chocolate spot with respect to leaf position. Int. J. Agric. Biol., 17:691701.

El-Zahaby, H.M., M.Y. Hafez and Z. Király. (2004). Effect of reactive oxygen species on plant pathogens in planta and on disease symptoms. ActaPhytopath.Entomol. Hung., 39:325-345.

Emiko, H., K. Masanori, A.Daigo and T. Masayuki. (2008). Pre-inoculation of cucumber roots with Verticillium lecanii (Lecanicillium muscarium) induces resistance to powdery mildew. Res. Bull. Obihiro Niv., 29:82-94. 
Ermias,T.T., F.G.Chemeda and S.W.M. Samuel. (2013). In vivo Assay for antagonistic potential of fungal isolates against faba bean (Vicia faba L.) chocolate spot (Botrytis fabaeSard.). Jordan Journal of Biological Sciences, 6:183-189.

Fry, S.C.(1982). Phenolic compounds of primary cell wall. Feruloylated disaccharides of D- galactoseand L-arabinose from spinach polysaccharide.Biochem. J., 203:493-504.

Garcia-Limones,C., A.Hervas, J.A.Navas-Cortes, R.M.Jimenez-Diaz and M.M. Tena. (2002). Induction of an antioxidant enzyme system and other oxidative stress markers associated with compatible and incompatible interactions between chickpea (Cicerarietinum L.) and Fusariumoxysporum f. sp. ciceris. Physiol. Mol. Plant Pathol.,61:325337.

Gili, S.S. and N. Tuteja. (2010). Reactive oxygen species and antioxidant machinery in abiotic stress tolerance in crop plants. Plant Physiol. Biochem.,48:909-930.

Gomez, K.A and A.A.Gomez. (1984). Statistical procedures for agricultural research. $2^{\text {nd }}$ ed. Jahn Wiley Sons, New York, USA.680 p.

Govrin, E.M. and A. Levine. (2000). The hypersensitive response facilitates plant infection by the necrotrophic pathogen Botrytis cinerea. Curr Biol., 10:751-757.

Hafez, Y.M. (2010). Control of Botrytis cinereaby the resistance inducers benzothiadiazole (BTH) and hydrogen peroxide on white pepper fruits under postharvest storage. Acta Phytopathol. Entomol. Hung., 45(1):1329.

Hafez, Y. M., R.Y. Mourad, M.Mansour and Kh.A.A.Abdelaal. (2014). Impact of non-traditional compounds and fungicides on physiological and biochemical characters of barely infected with Blumeria graminisf. sp. Hordei under field conditions. Egyptian Journal of Biological Pest Control, 24(2):445-453.

Haggag, W.M., A.L.Kansohand A.M. Aly.(2006). Proteases from Talaromycesflavusand Trichodermaharzianum: purification, characterization and antifungal activity against chocolate spot disease on faba bean. Plant Pathol Bull.,15: 231-239.

Hammerschmidt, R., E.M. Nuckles and J. Kuć. (1982). Association of enhanced peroxidase activity with induced systemic resistance of cucumber to Colletotrichumlagenarium. Physiological Plant Pathology, 20(1):73-82.

Hanounik, S.B. and N. Maliha. (1986). Horizontal and vertical resistance in Viciafabato chocolate spot caused by Botrytisfabae. Plant Disease, 70:770-773.

Hanounik, S.B., and L.D.Robertson. (1988). New sources of resistance in Viciafabato chocolate spot caused by Botrytis fabae. Plant Disease, 72:696-698.

Hückelhoven, R., J. Fodor, C. Preis and K.H. Kogel. (1999). Hypersensitive cell death and papilla formation in barley attacked by the powdery mildew fungus are associated with hydrogen peroxide but not with salicylic acid accumulation. Plant Physiol., 119: 1251-1260.

Khalil, S.A., and J.G. Harrison. (1981). Methods of evaluating faba bean materials for chocolate spot. FABIS Newsletter,3:51-52. 
Khalil, S.A., M. M. El-Hady, R.F.Dissouky, M.I. Amer and S.A. Omar.(1993). Breeding for high yielding ability with improved level of resistance to chocolate spot (Botrytis fabae) disease in faba bean (Vicia faba). J. Agric. Sci. Mansoura Univ.,18: 1315-1328.

Laloi, C., K.Apel and A.Danon. (2004). Reactive oxygen signaling: the latest news. Curr.Opin. Plant Biol., 7:323-328.

Lamb, C. and R.A. Dixon. (1997). The oxidative burst in plant disease resistance.Annu. Rev. Plant Physiol. Plant Mol Biol., 48:251-275.

Malik, C.P. and M.B. Singh. (1980). In: Plant Emymology and Histoenzymology. Kalyani Publishers.Indian and printed in Navin. Shanndara. Delhi, pp 54-56.

Malolepsza, U., and H. Urbanek. (2000). The oxidants and antioxidant enzymes in tomato leaves treated with o-hydroxyethylorutin and infected with Botrytis cinerea. Eur J Plant Pathol.,106:657-665.

Mayer, A.M., R.C. Staples and N.L.Gil-ad. (2001). Mechanisms of survival of necrotrophic fungal plant pathogens in hosts expressing the hypersensitive response. Phytochemistry,58:33-41.

Mellersh, D.G., I.V.Foulds, V.J.Higgins and M.C. Heath. (2002). $\mathrm{H}_{2} \mathrm{O}_{2}$ plays different roles in determining penetration failure in three diverse plantfungal interactions. Plant J.,29:257-268.

Mittler, R. (2002). Oxidative stress, antioxidants and stress tolerance. Trends Plant Sci., 7:405-410.

Mohamed,A.M., A. A.Saleh, R. A. Monira and R.M.AAbeer. (2012). Biochemical screening of chocolate spot disease on faba bean caused by Botrytis fabae. Afr. J.Microbiol. Res., 6(32):6122-6129.

Mohamed, C., A. Arbia and R. Azza. (2007). Phenolic compounds and their role in biocontrol and resistance of chickpea to fungal pathogenic attacks. Tunis. J. Plant Protect., 2(1):7-21.

Nawar, H.F. and J.D. Kuti. (2003). Wyerone acid phytoalexin synthesis and peroxidase activity as markers for resistance of broad beans to chocolate spot disease.J. Phytopathol.,151: 564-570.

Patykowski,J. and $\mathbf{H}$. Urbanek. (2003). Activity of enzymes related to $\mathrm{H}_{2} \mathrm{O}_{2}$ generation and metabolism in leaf apoplastic fraction of tomato leaves infected with Botrytis cinerea. J.Phytopathol.,151:153-161.

Peng, M., and J. Kuć. (1992). Peroxidase-generated hydrogen peroxide as a source of antifungal activity in vitro and on tobacco leaf discs. Phytopathology 1(82):696-699.

Rhaïem, A., Cherif, M., Kharrat, M., Cherif, M., and M. Harrabi. (2002). New faba bean genotypes resistant to chocolate spot caused by Botrytis fabae. PhytopatholMediterr.41:99-108.

Ride, J.P. (1983). Cell walls and other structural barriers in defence. In: Biochemical Plant Pathology. Calloz, J.A. (ed.), John Wiley and Sons, New York, USA.

Rojo, F.G., M. M. Reynoso, M.S.N.Chulze and A.M. Torres. (2007).Biological control by Trichoderma species of Fusarium solani causing peanut brown root rot under field conditions. Crop Protec., 26: 549-555.

Sahile, S., S. Ahmed,C. Fininsa,M.M. Abang and P.K. Sakhuja. (2008). Survey of chocolate spot (Botrytis fabae) disease of faba bean (Vicia faba L.) and assessment of factors influencing disease epidemics in northen Ethiopia. Crop Protection, 27:1457-1463. 
Schouten,A.,K.B.Tenberge,J.Vermeer,J.Stewart,L.Wagemakers,B.Williams on and L. Kan. (2002). Functional analysis of an extracellular catalase of Botrytis cinerea.Mol. Plant Pathol.,3:227-238.

Shi, H., R.Cui, B.Hu, X.Wang, S.Zhang, R.Liu and H. Dong. (2011). Overexpression of transcription factor AtMYB44 facilitates Botrytis infectionin Arabidopsis. Physiol Mol. Plant Pathol.,76:90-95.

Sillero, J.C., A.M.Villegas-Fernández, J.Thomas,M. M.Rojas-Molina, A.A.Emeran,M. Fernández-Aparicio and D. Rubiales. (2010). Faba bean breeding for disease resistance. Field Crops Res.,115:297-307.

Tarrad, A.M., Y.Y. El-Hyatemy and S.A. Omar. (1993). Wyerone derivatives and activities of peroxidase and polyphenol oxidase in faba bean leaves as induced by chocolate spot disease. Plant Sci., 89: 161-165.

Torres, A.M, B.Roman, C.M.Avila, Z.Satovic,D.Rubiales,J.C.Sillero, J.L.Cubero and M. T.Moreno. (2004). Faba bean breeding for resistance against biotic stresses: towards application of marker technology. Euphytica, 147: 67-80.

Unger, C.,S.Kleta, G.Jandl and A. von Tiedemann .(2005). Suppression of the defence related oxidative burst in bean leaf tissue and bean suspension cells by the necrotrophic pathogen Botrytis cinerea. J.Phytopathol., 153:15-26.

Vance, C.P., T.K. Kirk and R.T. sherwood. (1980).Lignification as a mechanism of disease resistance.Annu. Rev. Phytopath., 18:259-288.

von Tiedemann, A. (1997). Evidence for a primary role of oxygen species in induction of host cell death during infection of bean leaves with Botrytis cinerea.Physiol. Mol. Plant Pathol.,50:151-166.

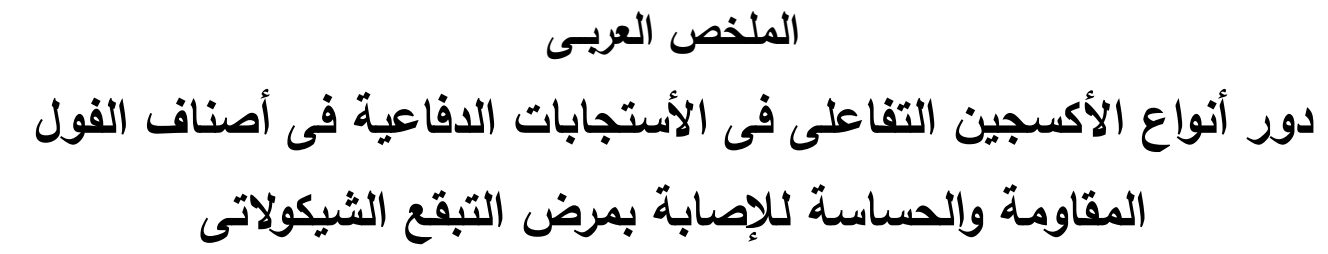

'مصطفى عامر،' إبراهيم السمرة، 'سوسن العبد 'ايمن عمر، 'منى عكريم و بعمرو عمران

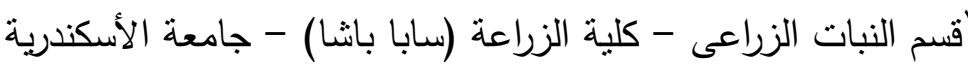

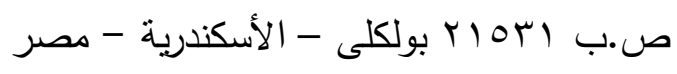

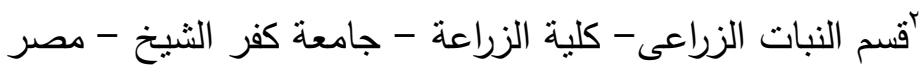

تمت الدراسة على ثلاثة أصناف من الفول أحدها مقاوم والآخر حساس للإصابة بفطر بوتريش فابى حيث تم

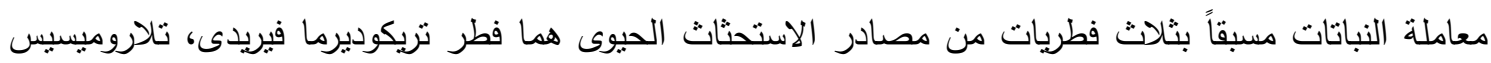

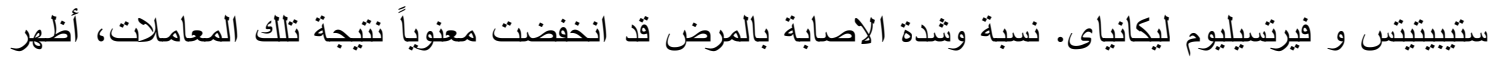

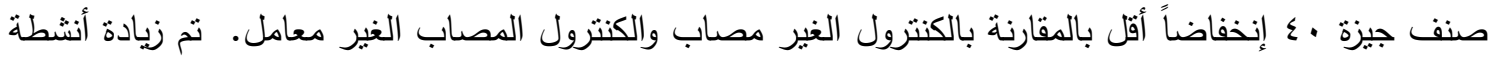

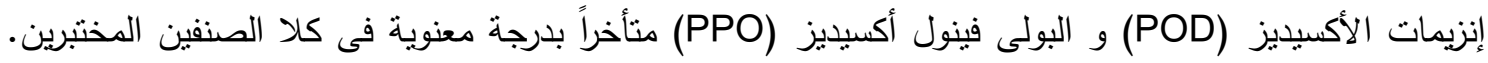

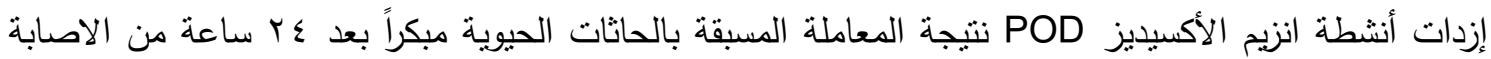

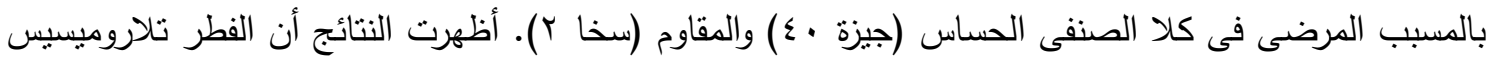


ستيبيتيتس قد سجل أعلى كفاءة لانزيم البولى فينول أكسيديز (PPO) حيث ارتفع معنوياً عند المعاملة المسبقة بفطر تلاروميسيس للصنف المقاوم (سخا r) وفطر فيرتيسيليوم ليكيناى للصنف الحساس (جيزة • ع) بالمقارنة

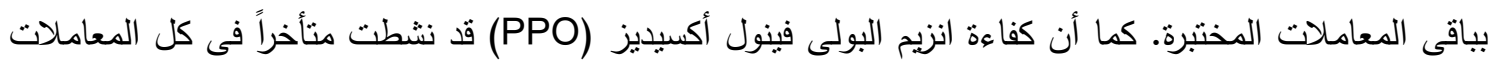
فيما عدا معاملة فطر تلاروميسيس للصنف جيزة •ـ. على الرغم من أن بعض المعاملات كانت قادرة على زيادة

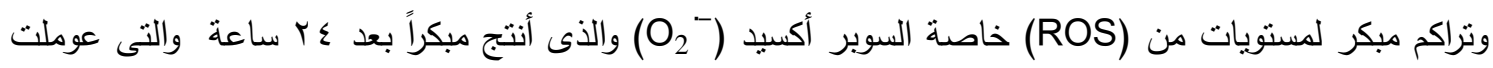

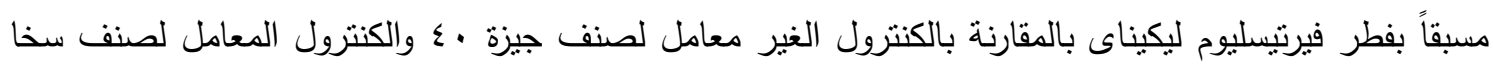

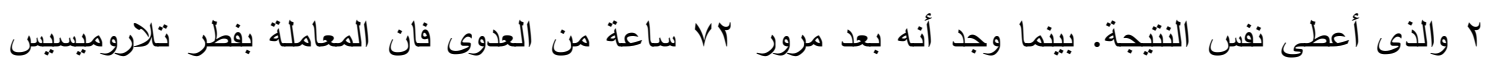

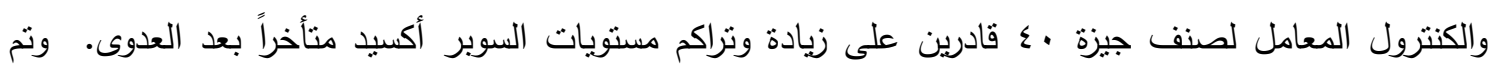

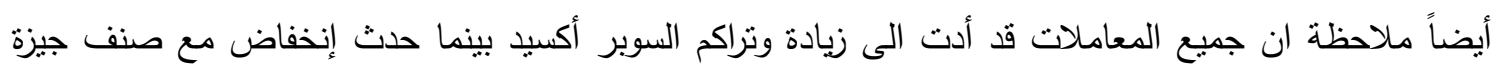

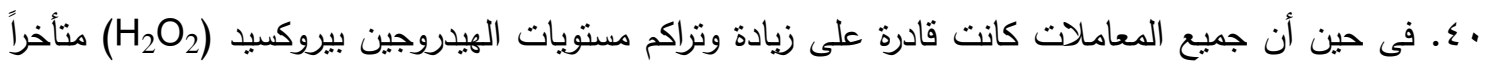

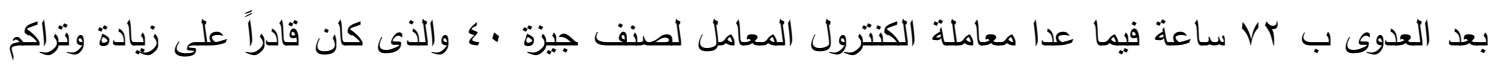
مبكر للهيدروجين بيروكسيد بعد \& ساعة من العدوى، وقد لوحظ أيضاً أن جميع المعاملات قد عملت على على ارتفاع

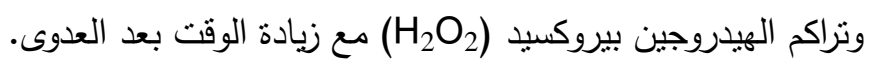


